\title{
The effect of students of sports management and coaching education department on entrepreneurial tendencies of career plans
}

\author{
Mustafa Vural, Yaşar Çoruh \\ Ağrı İbrahim Çeçen Üniversitesi, Beden Eğitimi ve Spor Yüksekokulu Ağrı, Turkey
}

\begin{tabular}{l} 
Article Info \\
\hline Article history: \\
Received Dec 12, 2018 \\
Revised Feb 22, 2019 \\
Accepted Mar 17, 2019 \\
\hline
\end{tabular}

Keywords:

Career

Entrepreneurship

Management

Planning

Sport

\begin{abstract}
This study investigated the effect of career planning of the students in the Ağrı Ibrahim Ceçen University department of sports management and the coaching education department on entrepreneurial tendencies. The research group consisted of 161 students who studying in Ağr1 Ibrahim Çeçen University Sports Management and Coaching Department. In the study, "Personal Career Planning Scale", which was developed by a reasearcher "Entrepreneurial Tendency Scale", which was developed by another researcher and "Personal Information Form", which was prepared by the researcher was used as a data collection tool. Spearman Correlation (r) coefficient technique was used to reveal the relationship between the career planning sub-dimensions and the entrepreneurial tendencies of the students. The effect between dependent and independent variables of the study was tested by regression analysis. In the correlation analysis performed at the end of the study, it was found that there was a positive relationship between all sub-dimensions of career planning scale and there was a positive and moderate relationship between the career planning and sub-dimensions and entrepreneurial tendencies. As a result of the regression analysis, the subdimension of defining opportunities and planning sub-dimension from the career planning has significantly affected the entrepreneurship and it explains $41 \%$ of the changes in entrepreneurship. It is possible to say that the participants who have the opportunities and have a plan are more entrepreneurs.
\end{abstract}

Copyright $(2019$ Institute of Advanced Engineering and Science. All rights reserved.

\section{Corresponding Author:}

Mustafa Vural,

School of Physical Education and Sports

Ağrı İbrahim Çeçen University

Erzurum Yolu 4 Km 04100 Merkez, Ağrı, Turkey

Email: mustafaavurall@gmail.com

\section{INTRODUCTION}

Together with the rapidly changing and developing technology, the demands and desires of people also change. With this change, many opportunities and chances can find individuals. Although the evaluation of opportunities and chances will be higher by the entrepreneurial individuals, it will also provide many benefits to the individual in career planning. Although the entrepreneurial individuals will turn many opportunities into benefits, they will also go on career planning for their future. The entrepreneur is the person who imagines, seeks, chases the opportunities and is ready and waiting for the opportunities, by going beyond the current resources and talents. It is the person who supplies the appropriate resources and capabilities that receive the opportunities and who is shaping, marketing, expecting to benefit by making it useful in innovation [1]. Individuals with entrepreneurial spirit always have a desire for success. Individuals with this characteristic do not get pleasure from routine situations and focus on producing new ideas. They 
are in the pursuit of continuous work and production, and therefore many entrepreneurs are in intense work pressure and refrain from delegating the authority. Qualifications for the success of entrepreneurial individuals; are being ready, creative, foresight and analysis ability, quick decision and giving confidence and rationality [2].

Entrepreneurship has maintained its importance for years by attracting the attention of different societies as it brings light on an economic thought in the center of people and society [3]. Entrepreneurship; is the process of developing a new idea by an individual who launches an initiative, adding value to processes and methods, resulting in new products or developing a new business [4]. The concept of entrepreneurship, which has an important place in recognizing and making the present and future opportunities available, is also an energetic structure for the actualization of new and creative ideas by providing a dynamic structure to the process of vision and creativity within the framework of changes [5]. The actualization of new and creative ideas is not only important in terms of creating a vision, but also important in terms of career planning.

According to Hughes, career "is the directing of individuals themselves towards social order and requirements of the work"[6]. Career is defined by taking the experiences of the employees through the progress they have made in achieving the individual and organizational goals that have been determined throughout their business life, and the experiences they acquired during this progress [7-9]. Career planning is a roadmap for achieving the goals determined in career development [10]. It is a decision-making process that involves the revision of career options, by considering the talents and interests of individuals, the determination of career goals and planning development activities [11]. Career planning is a long-term process that begins with the choice of work, getting into the work, progress in the work, change of work and including retirement [12].

Career planning process takes place on an individual and organizational dimension [13]. $\mathrm{Ng}$ et al. stated that individuals' success in their careers contributed to the organizational success, gathered the elements that affect career success in four categories: human capital, organizational support, sociodemographic elements of the individual and constant personality characteristics [14]. If the career plans that determined by the organization match with the employees' own plans, the level of commitment and satisfaction in the organization increases and the search for alternative jobs decreases [15]. According to Baruch, organizations have a more active role in career planning in the traditional approaches, whereas individuals have more responsibility in contemporary understanding [16]. The ideal one is making synchronized individual and organizational career plans that will benefit both parties, considering the personal and individual characteristics of the individuals, while determining career paths and development programs [17].

\section{RESEARCH METHOD}

In this study, "Survey Model", one of the most widely used of empirical research (observational) models, was used in education and sports sciences. Empirical research consists of the research carried out by using questionnaires or scales by developing hypotheses in cases where the researchers want to test and answer the questions, which they want to find the answers, whether the questions are correct or not. In empirical studies, the researchers include the obtained data to test their hypotheses in statistical analysis. Survey model studies included in empirical studies are known as descriptive research method used to determine the research subject characteristics of the large sample groups such as: age, gender, marital status [18].

The population of the study consisted of students in the sports management and coaching education department at the İbrahim Çeçen University. The sample group of the study consisted of 161 students in the school who participated in the survey at the time the survey was conducted.

In the study, personal career planning scale developed by Erdoğan [19] and entrepreneurial tendency scale developed by Y1lmaz and Sünbül [20] were used as the data collection tool.

\subsection{Entrepreneurial tendency scale}

Y1lmaz and Sünbül describe the validity and reliability studies and scale they used in the scale development as follows. The scale is arranged in the form of a 5-point scale in the likert type from "Very frequent" (5) to "Never" (1). Cronbach Alfa reliability analyzes and factor analysis (validity analysis) was performed on the data obtained after the trial. As a result of factor analysis performed by Principal Components Analysis, it was seen that all items were collected in one dimension. As a result of reliability analysis, the Cronbach Alfa reliability coefficient of the scale was 0.90. The Cronbach Alfa value is a coefficient ranging from 0 to 1 , which is considered to be high in reliability of the scale as this number approaches 1 . The reliability coefficient of the university students' entrepreneurship scale was calculated as

Int. J. Eval. \& Res. Educ. Vol. 8, No. 2, June 2019: 351 - 355 
0.90. After factor analysis, item-test correlations were calculated for each item. Calculated correlation coefficients range between 0.40 and 0.66 . These findings indicate that the scale and each item in the scope of the scale have a consistent distribution in the same direction with the characteristics that the scale aims to measure [20].

\subsection{Personal career planning scale}

In the Scale developed by Erdoğan, twenty questions, which were created by using the 5-point Likert scale as1-strongly disagree and 5-totally agree, were addressed to participants. While preparing the survey questions, the career planning questions were formed through four basic factors. These are; selfevaluation, recognition of opportunities, setting goals and making plan. Personal success questions are; four main factors: being ambitious and achieving, superiority and being different, focusing and having individual responsibility. While carrying out the reliability analysis of the developed questionnaire, an application was performed on 40 academicians in the preliminary stage and the reliability of the Likert type questionnaire was determined by "Alpha Test". As a result of the analysis Alpha value of the survey was; 0.942 . This is considered to be reliable because it is a value close to 1.000. [19].

\section{RESULTSAND DISCUSSION}

Spearman Correlation (r) coefficient technique was used to reveal the relationship between the career planning sub-dimensions and entrepreneurial tendencies of the students who attended the survey. The effect between dependent and independent variables of the study was tested by regression analysis. The correlation matrix included average and standard deviation values of variables is shown in Table 1.

Table 1. Correlation matrix, average and standard deviation values of variables

\begin{tabular}{|c|c|c|c|c|c|c|}
\hline & Career Planning & $\begin{array}{c}\text { Self- } \\
\text { Evaluation }\end{array}$ & $\begin{array}{c}\text { Recognition of } \\
\text { Opportunities }\end{array}$ & $\begin{array}{l}\text { Setting } \\
\text { Goals }\end{array}$ & Making Plan & $\begin{array}{c}\text { Entrepreneuria } \\
1 \text { Tendency }\end{array}$ \\
\hline Career Planning & 1 & & & & & \\
\hline Self-Evaluation & $.819^{* *}$ & 1 & & & & \\
\hline $\begin{array}{c}\text { Recognition of } \\
\text { Opportunities }\end{array}$ & $.749^{* *}$ & $.532^{* * *}$ & 1 & & & \\
\hline Setting Goals & $.883^{* *}$ & $.681^{* *}$ & $.520^{* *}$ & 1 & & \\
\hline Making Plan & $.877^{* *}$ & $.629^{* *}$ & $.518^{* *}$ & $.769^{* *}$ & 1 & \\
\hline $\begin{array}{c}\text { Entrepreneurial } \\
\text { Tendency }\end{array}$ & $.599^{* *}$ & $.538^{* *}$ & $.434^{* *}$ & $.515^{* *}$ & $.568^{* * *}$ & 1 \\
\hline $\mathrm{X}$ & 3.91 & 4.06 & 3.71 & 3.96 & 3.89 & 3.75 \\
\hline SS & .683 & .824 & .679 & .793 & .771 & .608 \\
\hline $\mathrm{N}$ & 161 & 161 & 161 & 161 & 161 & 161 \\
\hline
\end{tabular}

When Table 1 was examined, it was determined that there was a strong positive relationship between career planning and all sub-dimensions. The relationship between the career planning and its subdimensions were found at different levels. When we look at entrepreneurship and career planning, it was determined that there was a positive and moderate relationship between its sub-dimensions including selfevaluation, recognition of opportunities, setting goal and making plan sub-dimensions.

The regression analysis results performed to determine the relationship between entrepreneurial tendency and career planning sub-dimensions $(n=161)$ is shown is Table 2 . When Table 2 was examined, it was determined that recognition of opportunities and making plan dimensions from the sub-dimensions of the career planning in regression analysis, which was performed to determine the effect between the career planning and entrepreneurship, had a significant effect on the entrepreneurial tendency. According to the regression model, this effect was determined as $41 \%$. The sub-dimensions of recognition of opportunities and making plan affect the entrepreneurial tendency positively.

Table 2. Regression analysis results performed to determine the relationship between entrepreneurial tendency and career planning sub-dimensions

\begin{tabular}{lcccccc}
\hline \multirow{2}{*}{ Independent Variables } & \multicolumn{6}{c}{ Independent Variables: Entrepreneurial Tendency } \\
& $\mathrm{R}$ & $\mathrm{R}^{2}$ & $\mathrm{~F}$ & $\beta$ & $\mathrm{t}$ & $\mathrm{p}$ \\
\hline Self-Evaluation & & & & .157 & 1.426 & .156 \\
Recognition of Opportunities & \multirow{2}{*}{.640} & .410 & 27.06 & .203 & 2.369 & .019 \\
Setting Goals & & & 2 & .056 & 0.439 & .661 \\
Making Plan & & & & .305 & 2.634 & .009 \\
\hline
\end{tabular}

The effect of students of sports management and coaching education department on ... (Mustafa Vural) 
Considering the findings of the study, it was determined that there was a positive relationship between career planning and the entrepreneurial tendencies of the participants. Positive relationships between the career planning and sub-dimensions were also revealed.

In the test results, performed to reveal the effect between the two variables, it is concluded that recognition of opportunities and making plan sub-dimensions from the career planning sub-dimensions had a significant positive effect on the entrepreneurial tendencies of the participants. According to this result, it is possible to say that the participants who have the opportunities are more entrepreneur. It is possible to say that the participants who have a plan and making plan are more inclined towards entrepreneurship, which means the planned people become entrepreneurs to realize these plans.

When the related literature is analyzed, Solmaztürk, in his study conducted in universities in Istanbul, found that the dimension of entrepreneurial tendency, which has the most significant relationship with the dimensions of career tendency, is more effective and that this relationship is mostly provided by the organizational support. At the same time, in other sub-dimensions, it was concluded that Aggressive competition, innovation and risk-taking dimension has only direct effect on career anchors [21]. We concluded that there are parallel results with our research results. In other words, it is possible to say that those who are in a career tendency are in an entrepreneurial tendency.

\section{CONCLUSION}

An individual who is planning a career is in a variety of efforts to carry out her/his career, but at the same time, she/he is always ready to have the opportunities. In this context, entrepreneurial features will emerge to realize all these. In other words, it was determined and supported by the results of current study and the studies in the literature that an individual making career planning is an entrepreneur.

\section{REFERENCES}

[1] Bedük A., "Karşılaştırmalı İşletme Yönetim Terimleri Sözlüğü," Atlas Kitabevi Yayınları, Konya, 2012.

[2] Çelik, A., Akgemci A., "Girişimcilik Kültürü ve KOBI’’ler," Nobel Yayın Dağıtım, Konya, 1998.

[3] Onay, M., ve Çavuşoğlu, S., "İşletmelerde Girişimcilik Özelliğini Etkileyen Faktörler: İç Girişimcilik," Celal Bayar Üniversitesi İ̈BF Yönetim ve Ekonomi Dergisi, vol. 17(1), 2010.

[4] Hand, R. A., Entrepreneurial Analysis: A Study to Identify Traits and Demographics of Practicing Entrepreneurs, PhD Thesis, Capella University, Minneapolis, 2010.

[5] Kaplan, A., "Otel İşletmelerinde Bireysel Hizmet Odaklılığın iç Girişimcilik Performansı Üzerindeki Etkisi: Algılanan Çevresel Belirsizliğin Aracı Rolü," Yüksek Lisans Tezi, Nevşehir Hacı Bektaş Veli Üniversitesi Sosyal Bilimler Enstitüsü, Nevşehir, 2013.

[6] Hughes, EC. "Institutional Office and the Person," American Journal of Sociology, vol. 43, pp. 404-413, 1937.

[7] Hall, Douglas Tim and Associates, "Career Development in Organizations," San Francisco: Jossey-Bass Publishers, 1986.

[8] Gunz, H., Maury, P, "Introduction," Handbook of Career Studies, Edited by Hugh Gunz and Maury Peiperl, Thousand Oaks, CA: Sage, pp.1-10, 2007.

[9] Tortop, N, Özer, MA, Aykaç, B., Yayman, H., "İnsan Kaynakları Yönetimi," Ankara: Nobel Yayın Dağıtım, 2013.

[10] Anderson, S. D., "Planning for Career Growth," Personnel Journal, vol. 52, pp. 357-362, 1973.

[11] Cummings, T., Christopher, GW, "Organizational Development and Change," 9th Edition, Cengage Learning, Ohio: South-Western Educational Publishing, 2009.

[12] Paul, D., "Individual Career Planning," Annals of the Ovidius University, Economic Sciences Series, vol. 11(1), pp. 594-597, 2011.

[13] Çalık, T., Figen, E., "Kariyer Yönetimi; Tanımlar, Kavramlar, İlkeler," Gazi Kitabevi, Ankara, 2006.

[14] Ng, Thomas W. H. Lillian T. Eby. Kelly L. Sorensen. Daniel C. Feldman., "Predictors of Objective and Subjective Career Success: A Meta-Analysis," Personnel Psychology, vol. 58, pp. 367-408, 2005.

[15] Granrose, CS., James DP, "Matching Individual Career Plans and Organizational Career Management," Academy of Management Journal, vol. 30(4), pp. 699-720, 1987.

[16] Baruch, Y., "Transforming Careers: From Linear to Multidirectional Career Paths: Organizational and Individual Perspectives," Career Development International, vol. 9, no.1, pp. 58-73, 2004.

[17] Vallabhaneni, D., "What's Your MBA IQ? A Manager's Career Development Tool, Hoboken," New Jersey: John Wiley and Sons, Inc, 2009.

[18] Can, A., "SPSS İle Bilimsel Araştırma Sürecinde Nicel Veri Analizi," 2 Baskl, Pegem Akademi, Ankara, 2014.

[19] Erdoğan, HT, "Bireysel Kariyer Planlama İle Kişisel Başarı Arasındaki İlişkiye Yönelik Dumlupınar Üniversitesinde Bir Uygulama. Yüksek Lisans Tezi," Dumlupınar Üniversitesi Sosyal Bilimler Enstitüsü, 2009.

[20] Yılmaz, E., Sünbül, A.M., "Üniversite Öğrencilerine Yönelik Girişimcilik Ölçeğinin Geliştirilmesi," Selçuk Üniversitesi Sosyal Bilimler Enstitüsü Dergisi, vol. 21, pp. 196-203, Konya, 2009.

Int. J. Eval. \& Res. Educ. Vol. 8, No. 2, June 2019: 351 - 355 
[21] Solmaztürk, AB., Girişimcilik yöneliminin kariyer çapaları üzerindeki etkisinde algılanan örgütsel desteğin rolü. International Journal of Disciplines Economics \& Adminıstratıve Sciences Studies, vol. 4(7), pp. 64-86, 2018.

\section{BIOGRAPHIES OF AUTHORS}

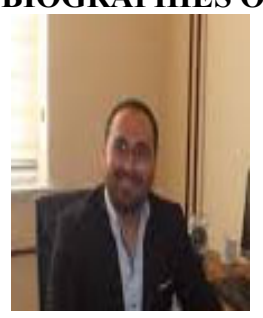

Researcher Mustafa Vural was born in Antalya. He took his bachelor degree from Selcuk University, School of Physical Education and Sports. He completed his PhD at Sakarya University. The working areas are sports management, physical education and sports, sports training. He is currently working as an assistant professor at İbrahim Çeçen university.

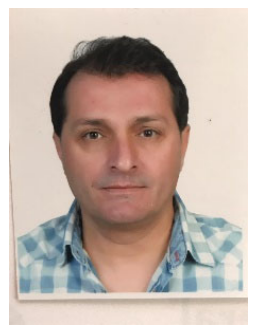

Researcher Yaşar Çoruh was born in Artvin. He took his bachelor degree from Samsun 19 mayıs University, School of Physical Education and Sports. He completed his PhD at Gazi University. The working areas are sports management, physical education and sports, sports training. He is currently working as an assistant professor at İbrahim Çeçen university. 